\title{
GANGGUAN KOMUNIKATIF DALAM TUTURAN LISAN ANAK AUTIS
}

\author{
Endang Sumarti \\ FPISH IKIP Budi Utomo Malang \\ e-mail: endangsumarti@yahoo.Ndim
}

\begin{abstract}
Abstrak
Penelitian ini bertujuan mendeskripsikan gangguan komunikatif dalam tuturan lisan anak autis. Data penelitian berupa rekaman dialog tuturan anak autis di Kota Malang. Pengumpulan data menggunakan teknik perekaman dan pengamatan. Hasil penelitian sebagai berikut. Pertama, ekolalia merupakan bentuk pengulangan kata, frasa, atau kalimat dalam tuturan dari orang lain. Kedua, abnormalitas pengucapan meliputi ketidaknormalan dalam proses, cara, dan perbuatan mengucapkan. Suara anak autis cenderung tersendat-sendat, dengan volume yang rendah, dan menunjukkan pola intonasi yang "aneh". Ketiga, gangguan produksi bahasa yaitu kesulitan dalam menghasilkan kata-kata dari sistem simpanan auditorisnya untuk menyampaikan keinginannya.
\end{abstract}

Kata kunci: gangguan komunikatif, tuturan lisan, anak autis

\section{COMMUNICATIVE DISORDERS IN ORAL SPEECH OF AUTISTIC CHILDREN}

\begin{abstract}
This study aims to describe communicative disorders in oral speech of autistic children. The research data were in the form of the recording of dialogues of autistic children in Malang. The data collection used recording and observation techniques. The results of the study are as follows. First, ecolalia is a form of repetition of words, phrases, or sentences in others' speech. Second, abnormalities of pronunciation include abnormalities in the process, manner, and act of utterance. The voice of an autistic child tends to be halting with a low volume, and shows a "strange" intonation pattern. Third, the language production disorder is the difficulty in generating the words from the auditory deposit system to express ideas.
\end{abstract}

Keywords: communicative disorders, oral speech, autistic children

\section{PENDAHULUAN}

Berbahasa merupakan tindak menyampaikan dan menafsirkan pesan antarpersonal dalam konteks tertentu. Melalui bahasa, penutur melakukan tindak menyampaikan pesan agar dipahami mitra tutur sesuai dengan gagasan yang ada dalam pikirannya. Anak autis terbatas kemampuan komunikasinya untuk dapat mengungkapkan diri dengan efektif dan efisien (Puspita, 2008:24). Hal ini disebabkan adanya gangguan kognitif pada di- rinya. Gangguan kognitif tersebut berpengaruh terhadap praktik pemrosesan informasi dan keterampilan berkomunikasi mereka. Informasi yang didengar, dilihat, dirasakan, diolah dengan cara yang berbeda dengan anak normal. Keadaan ini oleh Peters (2004:17) dinamakan sebagai gangguan kualitatif dalam komunikasi dan interaksi sosial.

Gangguan kognitif pada diri anak autis menyebabkan timbulnya kegagalan dalam berkomunikasi sehingga mereka 
tidak mampu secara efektif menghubungkan tuturan yang satu dengan yang lainnya. Sebagaimana dikatakan Sheinkopt (dalam Cumming, 2009) bahwa anak autis tidak mengalami kesulitan dalam mengekspresikan suku kata yang bagus (misalnya celotehan yang umum). Namun anak tersebut memperlihatkan pelemahan yang berarti pada kualitas vokal (misalnya fonasi yang tidak lazim). Vokalisasi awal yang tidak lazim menandai timbulnya masalah dalam tuturan dan perkembangan bahasa pada anak autis.

Secara verbal terdapat beberapa abnormalitas yang khas pada bahasa dan tuturan anak autis. Sebagaimana dikatakan oleh Woolfolk \& Carrow (1982) abnormalitas pada anak autis meliputi ekolalia, perkembangan kosakata yang tidak teratur, pembalikkan kata ganti, serta kesilapan pragmatik dan morfosintaktik. Juga lazim didapati adanya abnormalitas pengucapan dan suara. Cumming (2009) mengatakan bahwa anak autis itu gagal menggunakan bahasa dengan cara yang tepat dan efektif dalam wilayah situasi komunikatif.

Abnormalitas yang ada pada anak autis menyebabkan tuturan mereka berbeda dengan anak normal. Dalam pemroduksian tuturannya, anak autis menggunakan perilaku bahasa verbal yang sangat sederhana, yakni satu atau dua kata, yang diikuti dengan bahasa nonverbal. Gangguan kognitif yang terjadi pada anak autis menyebabkan terjadinya gangguan komunikasi. Kesulitan produksi bahasa juga merupakan salah satu bentuk gangguan komunikatif dalam tuturan lisan anak autis. Kesulitan produksi bahasa tersebut juga disebabkan adanya kesulitan yang dialami anak autis dalam menarik kaitan antara informasi satu dengan informasi yang lain dari mitra tuturnya. Anak autis sulit menarik simpulan generalisasi sehingga sulit menarik kaitan antara satu informasi dengan informasi lain (Puspita, 2008:55).
Anak autis kesulitan dalam mengembangkan komunikasi verbal. Mereka gagal dalam memahami apa yang dituturkan kepada mereka. Masalah komunikasi pada anak autis ini menunjukkan adanya interaksi antara berbagai macam dimensi bahasa. Hal ini menyebabkan anak autis tidak hanya gagal mengembangkan komunikasi interpersonal, tetapi juga gagal mengembangkan konsep yang diperlukan untuk membentuk isi bahasa. Keadaan ini menggiring pada melemahnya kinerja bahasa, yang diiringi dengan abnormalitas pada sistem semantik dan pragmatik. Defisit kognitif inti dalam autisme terdiri atas kegagalan dalam mengaitkan keadaan mental baik dengan pikiran seseorang itu sendiri maupun dengan pikiran orang lain (Cumming, 2009).

Berdasarkan uraian di atas, kajian terhadap gangguan komunikatif dalam tuturan lisan anak autis menarik untuk dikaji. Dengan mengetahui gangguan komunikatif dalam tuturan lisan anak autis ini diharapkan dapat memberikan masukan bagi orang tua, guru, dan terapis untuk melatih komunikasi pada anak autis tepat pada sasarannya. Selain itu hasil penelitian ini diharapkan agar bisa membantu meningkatkan dan mendorong anak autis bisa berkomunikasi secara efektif minimal untuk memenuhi kebutuhan untuk berkomunikasi sehari-hari.

\section{METODE PENELITIAN}

Penelitian ini menggunakan pendekatan kualitatif. Data penelitian ini berupa rekaman dialog tuturan anak autis yang disikapi sebagai simbol-simbol kebahasaan yang mengkonstruk gangguan komunikatif: (1) ekolalia (2) abnormalitas pengucapan, dan (3) kesulitan produksi bahasa dalam tuturan lisan anak autis. Sumber data penelitian adalah anak autis di kota Malang. Dalam penelitian ini, peneliti memposisikan diri sebagai instrumen utama. Sebagai instrumen utama, 
dalam melakukan penelitian ini, peneliti memegang peran kunci, baik dalam pengumpulan data, penganalisisan data, maupun penyimpulan temuan penelitian. Teknik pengumpulan data yang digunakan dalam penelitian ini adalah teknik perekaman dan pengamatan. Teknik analisis data yang digunakan dalam penelitian ini adalah model interaktif.

\section{HASIL DAN PEMBAHASAN}

Sesuai dengan fokus penelitian dikemukakan temuan gangguan komunikatif dalam tuturan lisan anak autis meliputi ekolalia, abnormalitas pengucapan, dan kesulitan produksi bahasa. Ketiga hal tersebut secara rinci dipaparkan sebagai berikut.

\section{Ekolalia}

Ekolalia merupakan bentuk pengulangan kata, frasa, atau kalimat dalam tuturan dari orang lain. Pada umumnya setiap anak mengalami masa perkembangan ini. Pada usia tertentu, anak mengalami proses ekolalia (membeo). Demikian pula dengan anak autis tetapi yang membedakan adalah derajat ekolalianya dan lama/ waktu dalam tahap perkembangan ini ( $\mathrm{Yu}$ wono, 2009:68). Anak-anak pada umumnya mengalami masa ini cukup singkat dan derajat ekolalia yang cepat berubah menjadi fungsional dan bermakna sosial yang lebih baik. Sedang pada anak autis cenderung ditemukan ekolalia yang derajat ekolalianya tinggi dan kurang bermakna.

Ekolalia adalah pengulangan katakata atau kalimat, segera atau tertunda dan sering dikaitkan dengan autisme. Ekolalia hanya bisa dianggap suatu ciri autisme jika muncul pada usia mental yang lebih tinggi. Bagi seorang anak autisme dengan usia mental 5 tahun tidaklah normal jika masih menunjukkan ekolalia dan ini dianggap sebagai gangguan kualitatif. Ekolalia jarang terjadi ketika pesan yang ingin disampaikan dimengerti. Beberapa alasan anak autis cenderung ekolalia dalam berkomunikasi adalah ketidakpahaman anak autis dalam memahami konsep bahasa dalam konteks pragmatis komunikasi.

Dua jenis ekolalia yang sering dijumpai pada anak autis adalah ekolalia cepat atau ekolalia segera dan ekolalia lambat atau ekolalia tertunda. Ekolalia cepat atau sering disebut dengan ekolalia segera merupakan pengulangan tanpa makna terhadap suatu kata atau sekelompok kata yang baru didengarnya. Ekolalia lambat atau ekolalia tertunda misalnya jika anak autis di rumah, tiba-tiba ia mengulang perintah gurunya yang di dapatkan anak di sekolah. Bahkan ada anak autis yang mengingat kata atau frasa yang dikatakan orang lain dan digunakan dalam beberapa jam kemudian, keesokan harinya, seminggu, sebulan, bahkan setahun kemudian.

Dari hasil analisis data penelitian ini ditemukan tuturan anak autis yang menunjukkan indikasi adanya ekolalia. Hal dimaksud selengkapnya dipaparkan dalam kutipan berikut.

[1] G: "Berapa bagian itu?" (1)

AA: “Tiga”. (2)

G: "Yang diarsir...Ndii!"” (3) "Yang diarsir berapa bagian?" (4) (Andi tidak memperhatikan $\mathrm{Bu}$ Rini)

AA1: "Arsir". (5)

AA2: "Satu" (6)

AA3: “Tiga".(7)

G: "Sa..Satu per.. satu, dua, tiga". (8) "Satu per tiga". (9) "Ira, boleh tukar tempat duduk sama Andi". (10) "Biar Andi tidak ramai saja". (11) (memegang lengan Ira).

Konteks: Dituturkan ketika pembelajaran matematika berlangsung. Bu Rini menjelaskan konsep sepertiga bagian kepada anak autis. (BGKE: Kata)

Kutipan [1] tersebut merepresentasikan bentuk gangguan komunikatif dalam tuturan anak autis berupa ekolalia. Anak autis melakukan ekolalia terhadap 
pertanyaan dan perintah karena mereka tidak mengerti atau tidak mengetahui bagaimana harus merespon. Tuturan (5) tersebut dikatakan sebagai gangguan komunikatif ekolalia karena berdasarkan deskripsi data pada tuturan tersebut terungkap pengulangan kata dilakukan anak autis pada saat ditanya Bu Rini. Melalui tuturan (5) tersebut pengulangan kata "arsir" diungkapkan Andi tanpa disadari atau dipahami makna kata yang diungkapkan tersebut. Pertanyaan yang diajukan Bu Rini kepada Andi melalui tuturan (3) dan tuturan (4) tentang berapa bagian yang diarsir dari gambar tersebut, tidak dijawab oleh Andi, tetapi malah diulang kata "arsir" tersebut melalui tuturannya. Andi melakukan pengulangan tersebut karena dia tidak memahami makna pertanyaan yang disampaikannya.

Ekolalia yang dilakukan Andi dalam tuturan tersebut adalah ekolalia segera. Dikatakan ekolalia segera karena begitu tuturan selesai diungkapkan Bu Rini, Andi langsung melakukan pengulangan kata dari kalimat tersebut.

Dalam konteks yang lain, anak autis juga melakukan ekolalia. Hasil analisis data tuturan ekolalia anak autis yang ditemukan dalam penelitian ini sebagaimana tampak pada kutipan [2] berikut.

[2] G: "Di sekolah". (1) “ Fahmi kalau ketemu temannya di sekolah menyapa apa tidak?". (2)

AA: "Menyapa". (3)

G: "Bagaimana menyapanya?". (4)

AA: "Bagaimana?".(5) (diam sejenak sambil tersenyum)

G: "Bagaimana kalau menyapa?" (6) "Pagi Aan". (7)

AA: "Pagi Aan". (8)

G: "Pagi Vin". (9)

AA: "Pagi Vin". (10)

Konteks: Dituturkan pada saat pembelajaran bahasa Indonesia. Bu Rini meminta anak-anak autis membuat kalimat berdasarkan gambar. (BGK: Ekolalia)
Berdasarkan deskripsi tersebut terungkap adanya gangguan komunikatif penggunaan tuturan berupa pengulangan kata dan kalimat yang dilakukan Fahmi. Pengulangan kata dan kalimat tersebut dilakukan secara langsung dan cepat karena dia termasuk anak autis yang sudah bagus komunikasi verbalnya. Melalui tuturan (3) Fahmi mengulang sebagian kalimat yang ditanyakan Bu Rini. Dilihat dari keterkaitan antara pertanyaan dan jawaban yang diungkapkan Fahmi, pengulangan kata yang dilakukan Fahmi melalui tuturan (3) tersebut termasuk ekolalia. Dikatakan ekolalia karena pengulangan tuturan tersebut tidak dipahami maknanya. Untuk memastikan bahwa Fahmi memahami makna pertanyaan tersebut, Bu Rini mengajukan pertanyaan lagi melalui tuturan (4). Karena Fahmi kurang memahami makna pertanyaan tersebut, dan kesulitan untuk menjawab bagaimana dia menyapa, maka Fahmi melakukan pengulangan dengan mengulang kata tanya yang diungkapkan Bu Rini melalui tuturan (5) yakni "bagaimana" kemudian diam sambil tersenyum.

Bagi anak autis yang sudah lancar berkomunikasipun masih ditemukan adanya ekolalia secara langsung terhadap tuturan yang baru saja didengarnya. Melalui tuturan (6) dan tuturan (7) Bu Rini memberi Ndintoh bentuk sapaan yang ditujukan pada teman Fahmi. "Bagaimana kalau menyapa?" (6) "Pagi Aan". (7) Melalui tuturan (8) dan tuturan (10) Fahmi melakukan pengulangan secara utuh kalimat yang diungkapkan Bu Rini. Pengulangan yang dilakukan anak autis biasanya memiliki ketepatan yang luar biasa. Pengulangan merupakan salah satu ciri gangguan komunikatif dalam tuturan lisan anak autis.

Tuturan lisan anak autis dalam kutipan [3] berikut merupakan bentuk gangguan komunikatif dalam tuturan anak autis berupa ekolalia. Melalui tuturan (2) Andi melalukan pengulangan terhadap 
ujaran yang baru saja didengarnya. Andi melakukan pengulangan sebagian dari ujaran pertanyaan yang diungkapkan $\mathrm{Bu}$ Rini, yaitu kata "sayur". Pengulangan segera terhadap sebagian ujaran yang baru didengar tersebut, paling sering terjadi ketika anak berinteraksi dengan mitra tutur, dan ternyata anak autis tidak mengetahui tanggapan yang tepat atas ujaran atau pertanyaan sebelumnya.

Untuk mengetahui apakah ujaran tersebut ekolalia atau bukan, Bu Rini menNdiba mengajukan pertanyaan lanjutan kepada Andi. Dari jawaban yang dilakukan anak autis terhadap pertanyaan lanjutan yang diberikan, guru mengetahui tuturan tersebut merupakan ekolalia atau bukan. Melalui tuturan (3) Bu Rini bertanya lagi kepada Andi, sayur, sayuran, ada wortelnya? Jika Andi menjawab ada atau ya, berarti tuturan (2) tersebut bukan ekolalia. Namun melalui tuturan (4) Andi tidak menjawab ada atau ya, tetapi Andi kembali melakukan ekolalia pada ujaran aslinya.

Anak autis mengalami gangguan kualitatif dalam bidang komunikasi ditandai dengan penggunaan bahasa yang aneh dan diulang-ulang. Pengulangan sebagian berupa kata "wortel" kembali dilakukan Andi ketika ditanya Bu Rini. Melalui tuturan (5) Bu Rini meminta Andi untuk menyebutkan nama sayur yang lain selain wortel. Peristiwa tutur tersebut berlangsung di ruang kelas waktu anak-anak autis istirahat sambil menggambar. Bu Rini juga menanyakan pengalaman Andi, dan rencana acara liburan Andi.

[3] G: Eh, Andi tadi pagi makan sayur apa tadi pagi? (1)

$A A$ : "Sayur" (2)

G: Sayur...Sayuran, ada wortelnya?"

(3)

AA: "Wortel" (4)

G: "Wortel terus?" (5)

AA: "Sudah..sudah..!" (6)

Konteks: Tuturan berlangsung ketika anakanak autis istirahat. Dalam situasi santai tersebut Bu Rini bertanya kepada Andi tentang menu sarapan Andi. (BGK: Ekolalia)

Berdasarkan paparan di atas dapat disimpulkan bahwa ekolalia merupakan salah satu gangguan komunikatif yang dimiliki anak autis. Temuan penelitian di atas sejalan dengan pendapat Woolfolk (1982) yang mengatakan bahwa diantara anak autis verbal, terdapat beberapa abnormalitas yang khas pada bahasa dan tuturannya. Abnormalitas ini meliputi ekolalia, perkembangan kosakata yang tidak teratur, pembalikan kata ganti, serta kesilapan pragmatik dan morfosintaktik.

Lebih lanjut Sarasvati (2004:139) berpendapat bahwa karena keunikan pola pikir dan tingkah laku mereka, anak-anak autis mengalami kesulitan dalam: (1) berkomunikasi dan berhubungan dengan orang lain, (2) mengerti apa yang dipikirkan orang lain, (3) mengembangkan kemampuan berbahasa. Anak autis sering mengulang kata yang didengar tanpa mengerti arti dari kata tersebut (ekolalia). Hal ini senada dengan pendapat Prasetyono (2008:59) yang menyatakan bahwa kualitas komunikasi anak autis tidak normal yang ditunjukkan dengan bahasa tidak lazim yang diulang-ulang atau stereotip.

\section{Abnormalitas Pengucapan}

Selain ekolalia bentuk gangguan komunikatif penggunaan bahasa dalam tuturan anak autis juga berupa abnormalitas pengucapan. Abnormalitas pengucapan merupakan ketidaknormalan dalam proses, cara, dan perbuatan mengucapkan. Suara anak autis cenderung tersendat-sendat, dengan kontrol tinggi rendah suara dan volume yang payah, dan menunjukkan pola intonasi yang "aneh". Suara mereka nampaknya kurang bervariasi, monoton dengan nada tinggi dan seperti burung betet. Keanehan suara lainnya meliputi suara parau, keras, dan 
hipernasalitas. Namun, suara anak autis paling sering digambarkan sebagai suara yang monoton.

Beberapa anak autis memiliki kesulitan dalam membedakan suara tertentu yang mereka dengar. Mereka kebingungan dengan kata-kata yang hampir sama, memiliki kesulitan untuk mengucapkan kata-kata yang sulit. Mereka biasanya memiliki kesulitan dalam mengontrol kekerasan (loudness) suara. Anak autis tidak menggunakan kualitas suara yang bagus untuk berkomunikasi.

Hasil analisis data ditemukan bentuk gangguan komunikatif dalam tuturan anak autis berupa abnormalitas pengucapan sebagaimana tampak pada kutipan [1] berikut.

[1] G: "Hari, sekarang beri salam temantemannya!". (1) "Selamat pagi Hanin". (2) (Memberi Contoh Hari).

$A A$ : "Ani" (3) (dengan suara dan intonasi yang tidak begitu jelas, Hari memberi salam kepada Hanin, sementara guru memegangi kepala Hari agar melihat anak yang diberi salam).

G: “Siapa?, Hanin”. (4) “Terus!” (5)

(Guru meminta Hari untuk meneruskan memberi salam teman yang lainnya).

$A A$ : "Ami". (6)

G: "Hari, Hari, ulangi!. Fahmi". (7)

AA: "Ami, .... Ami". (8)

Konteks: Dituturkan pada saat pembelajaran klasikal. Semua anak autis berkumpul dalam satu ruangan sebelum pembelajaran di kelas masing-masing dimulai. (BGK: Abnormalitas Pengucapan)

Berdasarkan deskripsi data tersebut terungkap bentuk abnormalisasi pengucapan berupa penghilangan sebagian kata dalam tuturan lisan anak autis. Abnormalisasi pengucapan merupakan salah satu bentuk gangguan komunikasi dalam tuturan lisan anak autis. Melalui tuturan (1) Pak Herman meminta Hari untuk mem- beri salam kepada teman-temannya. Hari memberi salam kepada teman-temannya secara bergantian sambil berjabat tangan. Dengan suara yang tidak begitu jelas, melalui tuituran (3) Hari memberi salam kepada Hanin. Walaupun sudah diberi Ndintoh Pak Herman bagaimana mengucapkan salam kepada Hanin, namun pada tuturan (3) tersebut kata selamat pagi tidak diucapkan Hari, dan nama Hanin yang terdengar dari tuturan Hari hanyalah "Ani". Hari menghilangkan sebagian kata "selamat pagi" dan konsonan " $h$ " dan " $n$ " dalam tuturan tersebut. Hari memberi salam kepada Hanin dengan suara pelan dan tidak begitu jelas.

Melalui tuturan (4) Pak Herman kembali bertanya kepada Hari dan membetulkan nama Hanin, dan meminta Hari untuk melanjutkan memberi salam teman-temannya. Untuk mengarahkan konsentrasi Hari, dalam tuturan tersebut Pak Herman berusaha untuk memegang dagu Hari. Tanpa mengucapkan kata selamat pagi, tapi langsung menyebut nama, Hari memberi salam kepada Fahmi sambil mengulurkan tangannya. Nama Fahmi tidak diucapkan secara jelas oleh Hari. Melalui tuturan (6) Hari hanya mengucapkan kata "Ami" dengan intonasi yang monoton dan volume suara yang tidak begitu terdengar. Beberapa konsonan dihilangkan dalam tuturan tersebut dihilangkan, yakni konsonan " $f$ " dan " $h$ ". Hari mengalami gangguan pengucapan dalam memprosuksi tuturannya.

Melalui tuturan (7) Pak Herman meminta Hari untuk mengulangi mengucapkan salam kepada Fahmi. Walaupun sudah diberi Ndintoh dan disuruh mengulangi tuturannya, namun Hari masih melakukan kesalahan seperti terlihat pada tuturan (8). Hari kembali ke Fahmi untuk memberi salam sambil mengulurkan tangan, dan melihat wajah Pak Herman. Melalui tuturan (8) Hari masih juga mengucapkan "Ami....Ami". Dari tuturan tersebut dapat dilihat bahwa suara anak 
autis cenderung tersendat-sendat, dengan kontrol tinggi rendah suara dan volume yang payah, dan menunjukkan pola intonasi yang "aneh." Suara mereka nampaknya kurang bervariasi, selau monoton dengan nada tinggi.

Selain tuturan di atas, abnormalisasi pengucapan dalam tuturan lisan anak autis dipaparkan sebagai berikut.

[2] G: "Kalau gule itu apakah dibakar?". (1)

AA: "Tidak". (2)

G: "Tidak". (3) "Kuahnya biasanya diberi apa?". (4)

AA: "Santan". (5)

G: "Oh, santan". (6) "Pintar sekali ya Mbak Hanin ya". (7) "Fahmi juga". (8) "Kalau Andi,...daging kambingnya dimasak apa ya?". (9)

AA: "Kiku...miler". (10)

G: "Ha..? Dimasak apa sayang". (11) "Daging kambingnya dimasak apa Ndi?". (12)

AA: "Dimasak..bubu..sao..kece". (13)

(tidak jelas suaranya)

G: “Oh, dibumbu saos kecap”. (14)

"Kalau ada kecapnya berarti warnanya apa Ndi?" ((15) "Apa Ndi?". (16)

AA: “Hitam". (17)

G: “Oh hitam...Apakah Andi suka?”. (18)

AA: "Puku". (19) (tidak jelas maknan-

ya)

G: "Apakah Andi suka?". (20)

AA: "Suka". (21) (suaranya hampir tidak kedengaran)

Konteks: Dituturkan ketika selesai pembelajaran bahasa Indonesia. Bu Dina melakukan tanya jawab dengan anak-anak autis tentang macam-macam masakan dari daging qurban. (BGK: Abnormalitas Pengucapan)

Tuturan tersebut merepresentasikan bentuk gangguan pengucapan dalam tuturan lisan anak autis. Gangguan pengucapan merupakan salah satu bentuk gangguan komunikatif yang lazim terjadi dalam tuturan anak autis. Peristiwa tutur tersebut berlangsung setelah pembelajaran bahasa Indonesia berakhir. Bu Dina melakukan tanya jawab dengan anak autis tentang cara memasak daging kambing dan macam-macam masakan dari daging kambing. Melalui tuturan (1) Bu Dina bertanya kepada Hanin apakah gule itu dibakar? Hanin melalui tuturan (2) menjawab "tidak".

Untuk mengetahui apakah jawaban yang diberikan Hanin tersebut merupakan pemahamannya, maka melalui tuturan (4) Bu Dina bertanya lagi kepada Hanin dengan pertanyaan "Kuahnya biasanya diberi apa?" Melalui tuturan (5) dengan jawaban yang singkat Hanin mengatakan "santan". Dari tuturan tersebut dapat dilihat bahwa Hanin memahami pertanyaan yang diterimanya dan mengetahui cara memasak gulai, sehingga dengan mudah dia menjawab pertanyaan Bu Dina.

Berbeda dengan jawaban yang diberikan Andi melalui tuturan (10). Walaupun semua anak autis sudah mendengar tanya jawab yang dilakukan Bu Dina dengan Hanin, namun karena anak autis sibuk dengan dirinya sendiri, maka ketika $\mathrm{Bu}$ Dina bertanya lagi kepada Andi tentang daging kambing itu dimasak apa, seperti terlihat pada tuturan (9), Andi tidak menjawab. Melalui tuturan (10) Andi menuturkan kalimat tetapi tidak bisa dipahami maknanya. Tuturan Andi yang terdengar adalah "Kiku...miler". Tuturan tersebut merupakan salah satu bentuk gangguan pengucapan yang sering terjadi pada anak autis. Tuturan tersebut diucapkan dengan nada datar dan tidak bisa dipahami maknanya.

Bu Dina tidak bisa memahami apa yang dituturkan Andi, melalui tuturan (11) dan diulang lagi melalui tuturan (12) Bu Dina bertanya lagi kepada Andi tentang daging kambing itu dimasak apa? Namun karena Andi mengalami hambatan dalam pengucapan dan suara, maka tuturan yang dihasilkanpun sulit untuk 
dipahami maknanya, seperti terlihat pada tuturan (13). Melalui tuturan tersebut diketahui adanya gangguan pengucapan berupa penghilangan konsonan " $m$ " pada kata "bumbu", konsonan " $s$ " pada kata "saos", dan konsonan " $p$ " pada kata "kecap", serta penggantian vokal " $a$ " dengan vokal " $e$ " pada kata "kecap" Bu Dina berusaha untuk menafsirkan makna tuturan yang dihasilkan Andi.

Untuk mengetahui apakah penafsirannya tersebut benar, melalui tuturan (14) Bu Rini mengatakan "Oh, dibumbu saos kecap". Bu Rini melanjutkan pertanyaan lagi kepada Andi melalui tuturan (15). Gangguan pengucapan dalam kutipan tersebut ditemukan lagi pada tuturan (19). Melalui tuturan tersebut Andi menghilangkan konsonan "l", mengatakan "Puku", pada kata "pukul" dengan tuturan yang tidak begitu jelas, sebagai jawaban atas pertanyaan Bu Dina melalui tuturan (18) tidak bisa dipahami maknanya. Melalui tuturan (20) Bu Rini mengulang pertanyaan pada tuturan (18), dan melalui tuturan (21) Andi menjawab pertanyaan Bu Dina dengan mengatakan "suka" dengan pengucapan yang tidak begitu jelas. Dari jawaban tersebut diambil kesimpulan bahwa melalui tuturan (19) yang diucapkan dengan jelas tersebut, yang dimaksudkan adalah "suka".

Dalam konteks lain, abnormalitas pengucapan dalam tuturan lisan anak autis sebagaimana tampak pada kutipan [3] berikut.

[3] G: "Oh, naik Mobil”. (1) “Di Mojokerto Andi makan apa di sana?". (2)

AA: "Ose-ose".(3) (menyebut osengoseng)

G: “Oseng-oseng". (4) "Oseng-oseng apa?". (5)

AA: "Baso". (6)

G: "Bakso. Ada baksonya, terus". (7)

AA: "Soto aya". (8)

G: "Makan soto ayam.Terus". (9)

AA: "Diam.

G: "Oh, makan oseng-oseng, bakso, soto ayam,terus?". (10)
AA: "Pangsi mie aya". (11)

G: "Pasit mie ayam". (12)

AA: "Sate aya...". (13)

G: "Sate ayam". (14)

AA: "Cilo".(15)

G: “Cilok. Oh Cilok. Apalagi?". (16)

AA: "Mangga". (17)

Konteks: Dituturkan di ruang kelas pada saat anak autis istirahat. Bu Rini dan Bu Dina bertanya kepada Andi, mengenai aktivitas yang dilakukannya selama lebaran di Mojokerto. (BGK: Abnormalitas Pengucapan)

Kutipan tersebut merupakan representasi bentuk gangguan pengucapan dalam tuturan anak autis. Gangguan pengucapan berupa penghilangan konsonan akhir kata dituturkan Andi ketika menjawab pertanyaan Bu Rini. Melalui tuturan (2) Bu Rini bertanya kepada Andi tentang makanan apa yang dia makan ketika di Mojokerto. Melalui tuturan (3) Andi menjawab pertanyaan Bu Rini dengan mengatakan "Ose-ose". "Ose-ose" pada tuturan tersebut dimaksudkan untuk menyebutkan kata "oseng-oseng". Tuturan Andi tersebut merupakan salah satu bentuk gangguan pengucapan berupa penghilangan konsonan " $n g$ ".

Selain pada tuturan (2) ditemukan beberapa bentuk gangguan pengucapan berupa penghilangan konsonan dilakukan Andi melalui tuturannya. Pada tuturan (6) penghilangan konsonan " $k$ " dilakukan Andi ketika menungkapkan kata "bakso". Melalui tuturan (6) tersebut Andi hanya mengucapkan "baso" untuk mengatakan "bakso".

Selain gangguan pengucapan berupa penghilangan konsonan dalam tuturannya, dalam deskripsi tersebut juga ditemukan adanya kesulitan anak autis dalam memahami tuturan yang ditujukan kepadanya. Hal ini bisa dilihat ketika Andi ditanya Bu Dina melalui tuturan (9), Andi hanya diam saja. Mengetahui Andi tidak bisa memahami makna pertanyaan yang ditujukan kepadanya, melalui 
tuturan (10) Bu Dina menyebutkan lagi makanan yang dimakan Andi sambil mengulang lagi pertanyaannya. Hal ini dilakukan Bu Dina untuk membantu Andi memahami pertanyaan yang dituturkannya. Namun melalui tuturan (11) Andi melakukan penghilangan konsonan " $t$ " dan konsonan " $m$ " melalui tuturannya ketika menuturkan kata "pangsit mie ayam". Melalui tuturan (13) Andi menghilangkan konsonan " $m$ " untuk mengucapkan "sate ayam". Begitu pula melalui tuturan (15) Andi mengatakan "Cilo" dan menghilangkan konsonan " $k$ " untuk menuturkan kata "cilok". Gangguan pengucapan yang dituturkan anak autis tersebut juga diikuti pada suara yaitu penyimpangan pada intensitas dan kualitas suara yang sangat lemah.

Dari uraian di atas dapat disimpulkan bahwa tuturan yang diucapkan anak autis seringkali tidak bisa dipahami dengan baik oleh mitra tuturnya karena adanya gangguan pengucapan dalam tuturan anak autis. Abnormalitas pengucapan merupakan salah satu bentuk gangguan komunikatif dalam tuturan lisan anak autis. Hal ini menyebabkan anak autis mengalami kesulitan untuk berinteraksi dan berkomunikasi dengan mitra tutur secara efektif. Prasetyono (2008:209) menjelaskan bahwa artikulasi atau pengucapan anak autis kurang sempurna karena adanya gangguan. Kesulitan pada artikulasi atau pengucapan anak autis meliputi substitution (penggantian), omission (penghilangan), distorsion (pengucapan untuk konsonan terdistorsi), indistinct (tidak jelas), dan addition (penambahan).

Senada dengan pendapat di atas, Maulana (2007:40) dan Handojo (2004:17) mengatakan bahwa gangguan kualitatif dalam bidang komunikasi anak autis seperti ditunjukkan oleh minimal satu dari gejala-gejala di bawah ini: (1) bicara terlambat atau bahkan sama sekali tidak berkembang, (2) bila bicara, bicaranya tidak dipakai untuk komunikasi, (3) se- ring menggunakan bahasa yang aneh dan diulang-ulang, cara bermain kurang variatif, kurang imajinatif dan kurang bisa meniru. Lebih lanjut Priyatna (2010:14) dan Veskarisyanti (2008:18) menjelaskan bahwa anak autis memiliki perilaku repetitif dan stereotif dalam penggunaan bahasa.

\section{Kesulitan Produksi Bahasa}

Produksi bahasa merupakan proses, cara, atau perbuatan memproduksi sistem lambang bunyi yang arbitrer, yang digunakan oleh anggota suatu masyarakat untuk bekerja sama, berinteraksi, dan mengidentifikasikan diri. Tujuan proses produksi ujaran adalah untuk menghasilkan seperangkat bunyi yang digunakan untuk menyampaikan gagasan kepada orang lain. Kesulitan produksi bahasa merupakan salah satu bentuk gangguan komunikatif dalam tuturan lisan anak autis.

Bentuk kesulitan produksi bahasa anak autis adalah kesulitan dalam memformulasikan bahasa dalam tuturannya. Mereka tidak dapat mengepaskan outputnya dengan apa yang ingin dikatakannya, sehingga menyebabkan masalah dalam penemuan kata, penghilangan bentuk, dan jeleknya perangkaian suku kata dan kata. Anak autis mengalami kesulitan dalam menghasilkan kata-kata dari sistem simpanan auditorisnya untuk mengekoding makna yang ingin dia ungkapkan. Dia mengetahui kata-kata namun tidak mudah dia kemukakan sehingga dia tidak bisa memproduksi bahasa dengan lancar dan runtut. Kalimat diproduksi dengan kata yang tidak berurutan dan kata-kata yang tidak dikenal diucapkan secara tidak benar.

Dalam berkomunikasi, anak autis juga mengalami kesulitan dalam memulai percakapan atau pembicaraan. Dalam aspek produksi bahasa, anak tidak bisa menyesuaikan outputnya dengan apa yang ingin dia dikatakan. Anak autis kurang 
memiliki kemampuan untuk menggunakan tuturan untuk berkomunikasi secara fungsional. Kadang kala anak autis mengeluarkan bahasa tetapi tidak dapat dimengerti oleh mitra tuturnya bahkan juga orangtuanya, sehingga pada saat "ngobrol tidak nyambung". Keadaan seperti ini dapat menyebabkan anak frustrasi karena keinginan tidak bisa dikomunikasikan, akibatnya, anaknya mengamuk dan berperilaku mengganggu atau merusak ataupun agresif terhadap lingkungan.

Hasil analisis data ditemukan kesulitan produksi bahasa dalam tuturan lisan anak autis sebagaimana tampak pada kutipan [1] berikut.

[1] G: "Andi tadi ke sekolah diantar siapa?". (1)

AA: (diam tidak menjawab, sambil garukgaruk pundaknya)

G: "Diantar siapa ke sekolah?". (2)

AA: "Naik mobil". (3)

G: "Oh..naik mobil". (4) "Diantar, diantar siapa?". (5)

AA: "Andi". (6)

G: "Eh, Andi tadi lho ke sekolah naik mobil diantar siapa?" (7) "Diantar, Eh, diantar Yang Kung apa Papa?". (8) (Memegang dagu Andi)

AA: "Papa". (9)

G: “Oh, diantar papa”. (10) “Eh, Andi tadi pagi sudah makan?". (11)

AA: "Suda". (12)

G: "Makan apa tadi nak?". (13)

AA: "Haaa.. eee...(14) (mengeluarkan suara yang tidak jelas maknanya)

G: "Makan...makan apa tadi pagi?" (15)

AA: "Haa..eeeee..". (16)

Konteks: Dituturkan sebelum pembelajaran matematika (mengenal uang) dan Sains dimulai. Bu Rini bertanya kepada Andi tentang aktivitas Andi di pagi Hari dan bagaimana Andi sampai di sekolah. (BGK: Kesulitan Pemroduksian Bahasa)

Berdasarkan deskripsi tersebut terungkap bentuk gangguan kualitatif dalam tuturan lisan anak autis. Bentuk gangguan komunikatif yang terungkap melalui tuturan tersebut adalah kesulitan produksi bahasa. Melalui tuturan (1) Bu Rini bertanya kepada Andi tentang siapa yang mengantar dia ke sekolah. Namun karena Andi mengalami kesulitan dalam memahami tuturan yang diungkapkan Bu Rini tersebut, maka Andi hanya diam, tidak menjawab pertanyaan tersebut sambil garuk-garuk pundaknya. Bu Rini kembali bertanya lagi kepada Andi dengan menggunakan kalimat yang berbeda, namun hakikatnya sama melalui tuturan (2). Andi memahami hakekat pertanyaan yang diungkapkan Bu Rini, hal ini bisa dilihat dari jawaban yang diberikan Andi melalui tuturan (3). Melalui tuturan (3) Andi mengatakan bahwa dia ke sekolah naik mobil.

Anak autis memang mengalami kesulitan dalam memahami tuturan orang lain. Walaupun jawaban tersebut tidak sesuai dengan pertanyaan Bu Rini, namun sedikit banyak sudah mendekati apa yang dimaksudkan Bu Rini. Mengingat anak autis mempunyai masalah berkaitan dengan pemahaman dan pemrosesan informasi yang diterima, maka untuk mempermudah proses berpikir Andi, melalui tuturan (8) Bu Rini memberikan alternatif pilihan jawaban kepada Andi sambil memegang dagunya untuk mengarahkan konsentrasi Andi. Melalui tuturan (9) Andi menjawab pertanyaan Bu Rini, bahwa yang mengantar ke sekolah adalah " Papa". Selain kesulitan dalam pemroduksian bahasa seperti yang diungkapkan di atas, pada tuturan (12) kutipan [1] tersebut juga ditemukan adanya gangguan pemroduksian bahasa tuturan anak autis berupa penghilangan konsonan " $h$ " pada akhir kata "sudah".

Dalam kegiatan komunikasi, anak autis membutuhkan perlakuan untuk keterampilan bercakap-cakapnya. Anak autis tidak suka membahas topik-topik yang disodorkan mitra tuturnya lebih dari satu atau dua menit. Hal ini dapat dilihat 
melalui tuturan (14) dan (16). Melalui tuturan (13) Bu Rini bertanya tentang menu makanan Andi tadi pagi. Melalui tuturan (14) Andi menanggapi pertanyaan Bu Rini melalui ungkapan yang tidak bisa dipahami maknanya. Hal ini menunjukkan bahwa Andi sudah jenuh dengan pertanyaan-pertanyaan yang diajukan $\mathrm{Bu}$ Rini. Belum puas dengan jawaban yang diberikan Andi, melalui tuturan (15) dengan menggunakan kalimat yang berbeda, Bu Rini menNdiba untuk bertanya lagi kepada Andi. Namun melalui tuturan (16) Andi menanggapi pertanyaan Bu Rini dengan kata yang tidak bisa dipahami maknanya.

Dalam konteks lain, kesulitan produksi bahasa yang dialami anak autis dipaparkan pada kutipan [2] berikut.

[2] G: "Jus strowberi. Enak Ndi rasanya Ndi?". (1)

AA: "Enak siip".(2)

G: "Enak sekali. Mak..". (3)

AA: "Maen".(4)

G: "Mak,...nyus. Heh Ndi, Andi makan sate apa?". (5)

AA: "Satee, gulii, enak".(6)

G: "Sate, gurih, enak. Sate apa, sate ayam apa sate kambing?". (7)

AA: "Sate kambing". (8)

G: "Oh sate kambing?" (9) " Gimana rasanya sate kambing Ndi?". (10)

AA: "Makan". (11)

G: "Rasanya". (12)

AA: "Manis". (13)

G: “Oh, manis. banyak kecapnya ya?". (14)

Konteks: Dituturkan pada saat pembelajaran bahasa Indonesia. Bu Rini dan Bu Dina menanyakan kepada Andi, aktivitas selama lebaran di Mojokerto. (BGK: Kesulitan Pemroduksian Bahasa)

Hasil analisis data ditemukan kesulitan produksi bahasa anak autis sebagaimana tampak pada tuturan (4). Berdasarkan deskripsi data tuturan (4) tersebut terungkap adanya ketidakse- suaian kata yang diproduksi anak autis dengan tuturan yang diungkapkan $\mathrm{Bu}$ Rini melalui tuturan (3). Bu Rini melalui tuturan (3) bermaksud menyatakan bahwa jus strowbery yang diminum Andi rasanya enak sekali "mak nyus". Namun Andi melalui tuturan (4) menanggapi tuturan Bu Rini dengan mengatakan "maen". Ungkapan yang dituturkan Andi melalui tuturan (4) tersebut terjadi karena adanya kesalahan persepsi yang dialami Andi.

Persepsi dan memori memainkan peran penting dalam pengembangan konsep dalam hubungannya antara konsep dan kode linguistik. Kesalahan pemahaman terhadap pertanyaan yang mengakibatkan kesalahan produksi tuturan ditunjukkan Andi melalui tuturan (6). Bu Rini melalui tuturan (5) bertanya kepada Andi tentang sate apa yang dimakan Andi. Melalui tuturan (6) Andi menjawab pertanyaan Bu Rini, dengan mengatakan bahwa sate yang dimakannya rasanya enak dan gurih, tanpa menyebutkan sate apa yang dimakan tersebut.

Melalui tuturan (10) Bu Rini bertanya, sate kambing yang dimakan Andi itu rasanya bagaimana? Namun karena Andi tidak memahami makna tuturan tersebut, kesalahan dalam produksi bahasa karena kesulitan pemahaman tersebut kembali dilakukan Andi. Melalui tuturan (11), Andi memproduksi tuturan yang tidak relevan dengan pertanyaan yang diajukan. Hal ini juga dilakukan Andi melalui tuturan (13) sebagai tanggapan atas pertanyaan Bu Rini melalui tuturan (12). Kesulitan pemroduksian tuturan pada data tersebut salah satu penyebabnya adalah adanya persepsi yang keliru dan kesulitan dalam menghasilkan kata-kata dari sistem simpanan auditorisnya untuk mengekoding makna yang ingin dia ungkapkan.

Selain tuturan yang sudah dipaparkan di atas, hasil analisis data menemukan kesulitan produksi bahasa sebagaimana tampak pada kutipan [3] berikut.

[3] G: "Tadi Mama telpon apa nggak?"

(1) 
AA: "Em.. Telpon". (2)

G: "Mama telpon". (3) "Ngomong apa?". (4) "Mama ngomong Apa?"

(5)

AA: "Papa" (6)

G: "Papa ngomong apa?" (7) "Bilang

apa ke Hanin tadi, Papa?" (8)

AA: "Diam" (9)

Konteks: Tuturan berlangsung pada waktu anak-anak autis istirahat. Bu Dina bertanya kepada Hanin tentang bagaimana khabar orang tuanya yang sedang menunaikan ibadah haji. (BGK: Kesulitan Pemroduksian Bahasa)

Kesulitan komunikatif dan kurang berkembangnya kemampuan berbahasa secara memadai lazim terjadi pada anak autis. Melalui tuturan (2) Hanin menanggapi pertanyaan Bu Dina dengan jawaban yang sesuai dengan pertanyaan yang diajukan, bahwa Mama Hanin yang sedang naik Haji menelponnya. Namun saat ditanya Bu Dina melalui tuturan (4) dan diulang lagi melalui tuturan (5) Mama ngomong apa? Hanin tidak menjawab dengan jawaban yang sesuai dengan pertanyaannya. Melalui tuturan (6) Hanin menjawab "Papa".

Berdasarkan deskripsi tersebut terungkap adanya kesulitan produksi bahasa yang dilakukan Andi karena adanya persepsi yang salah terhadap pertanyaan yang diterimanya atau kesulitan dalam memahami tuturan yang diterimanya. Kesulitan pemroduksian bahasa dapat dilihat lagi pada tuturan (9), Hanin hanya diam saja ketika ditanya oleh $\mathrm{Bu}$ Dina mengenai apa yang dibicarakan Hanin dengan Papanya melalui telepon.

Dari uraian tersebut dapat dilihat bahwa anak autis mengalami kesulitan dalam memproses tuturan yang diterimanya. Mereka mengalami kesulitan dalam merangkai informasi verbal dan sulit memahami bahasa verbal/lisan. Mereka mengalami kesulitan dalam berkomunikasi, baik komunikasi verbal maupun komunikasi nonverbal. Selain itu mereka juga mengalami kesulitan dalam mengatur, mengorganisir input sensoris yang masuk. Anak autis seringkali menggunakan alat komunikasi yang tidak tepat secara sosial dalam upaya mencapai tujuan-tujuan yang diinginkan.

Dari paparan di atas dapat disimpulkan bahwa komunikasi verbal merupakan sarana utama untuk menyatakan pikiran dan perasaan. Komunikasi verbal menggunakan kata-kata yang merepresentasikan berbagai aspek realitas individu. Anak autis tidak mampu menjalin hubungan sosial secara normal, bahkan tidak mampu untuk menjalin komunikasi dua arah. Kadang-kadang kata-kata yang digunakannya tidak sesuai artinya. Dengan adanya gangguan dalam perkembangan neurologis berat yang dialami anak autis, mempengaruhi cara seseorang untuk berkomunikasi dan berhubungan dengan orang lain di sekitarnya secara wajar. Pemahaman konsep tuturan sangat diperlukan.

Cumming (2009) berpendapat bahwa anak autis itu gagal menggunakan bahasa dengan cara yang tepat dan efektif dalam wilayah situasi komunikatif. Aspek pragmatik bahasa yang terganggu meliputi pemahaman dan produksi tuturan, penggunaan dan pemahaman bahasa nonharfiah dan sederet keterampilan bercakap-cakap, misalnya pengambilan giliran dalam berbicara. Anak autis mengalami gangguan perkembangan yang kompleks. Gangguan itu hampir meliputi seluruh aspek kehidupannya, antara lain komunikasi, interaksi sosial, gangguan dalam sensoris, pola bermain, perilaku khas, dan emosi.

Gangguan-gangguan tersebut jelas akan menghambat perkembangan anak autis. Penyebab keterlambatan bicara sangat banyak dan bervariasi. Mereka memiliki hambatan kualitatif dalam interaksi sosial artinya bahwa anak autis memiliki hambatan dalam kualitas berinteraksi dengan individu di sekitar lingkungan- 
nya. Mereka juga mengalami keterlambatan dalam berbicara dan berbahasa. Mereka mengalami kesulitan dalam memahami pembicaran orang lain yang ditujukan pada mereka, kesulitan dalam memahami arti kata-kata dan apabila berbicara tidak pada konteks yang tepat. Sering mengulang kata-kata tanpa bermaksud untuk berkomunikasi.

\section{SIMPULAN}

Berdasarkan hasil dan pembahasan dikemukakan simpulan penelitian sebagai berikut. Pertama, ekolalia merupakan salah satu gangguan komunikatif dalam tuturan lisan anak autis. Ekolalia mengacu pada pengulangan ujaran yang baru saja atau sudah lama didengar. Kedua abnormalitas pengucapan merupakan gangguan komunikatif anak autis meliputi ketidaknormalan dalam proses, cara, perbuatan mengucapkan. Suara anak autis cenderung tersendat-sendat, dengan kontrol tinggi rendah suara dan volume yang payah, dan menunjukkan pola intonasi yang "aneh". Ketiga gangguan produksi bahasa merupakan kesulitan anak autis dalam mengepaskan outputnya dengan apa yang ingin dikatakannya sehingga menyebabkan masalah penemuan kata, penghilangan bentuk, dan jeleknya perangkaian suku kata dan kata. Bentuk gangguan komunikatif penggunaan bahasa dalam tuturan anak autis bersifat kontinum. Walaupun sama-sama mengalami gangguan komunikatif, namun tingkat gangguannya beragam.

\section{UCAPAN TERIMA KASIH}

Artikel ini disarikan dari Disertasi yang berjudul Kompetensi Komunikatif dalam Tuturan Lisan Anak Autis pada Program Studi Pendidikan Bahasa Indonesia Program Pascasarjana Univesitas Negeri Malang. Ucapan terima kasih disampaikan kepada para pembimbing (1) Prof. Dr. H. Syukur Ibrahim, (2) Prof.
Dr. H. Dawud, M.Pd, (3) Prof. Dr. Djoko Saryono, M.Pd. Terima kasih kepada rekan-rekan S3 angkatan 2007/2008 atas diskusi dan saran kritisnya untuk penyempurnaan tulisan ini. Ucapan terima kasih juga disampaikan kepada Dewan Redaksi Jurnal Litera, terutama kepada ketua dan sekretaris yang telah bersedia mereview tulisan ini menjadi lebih baik.

\section{DAFTAR PUSTAKA}

Cummings, L. 2009. Clinical Pragmatics. Cambridge: Cambridge University Press.

Handojo. 2004. Autisma: Petunjuk Praktis dan Pedoman Materi Untuk Mengajar Anak Normal, Autis dan Perilaku Lain. Jakarta: Buana Ilmu Populer.

Maulana, M. 2007. Anak Autis: Mendidik Anak Autis dan Gangguan Mental Lain Menuju Anak Cerdas dan Sehat. Jogjakarta: Katahati.

Peeters, T. 2004. Autisme: Hubungan Pengetahuan Teoritis dan Intervensi Pendidikan Bagi Penyandang Autis. Jakarta: Dian Rakyat.

Prasetyono, D. S. 2008. Serba Serbi Anak Autisn (Autisme dan Gangguan Psikologis Lainnya: mengenal, menangani, dan Mengatasinya dengan Tepat dan Baik). Jogjakarta: DIVA Press.

Puspita, D. 2008. Warna-warni Kehidupan: Ketika Anak Autis Berkembang Remaja. Jakarta: Yayasan Autisme Indonesia.

Saraswati. 2004. Meniti Pelangi: Perjuangan Seorang Ibu Yang Tak Kenal Menyerah dalam Membimbing Putranya Keluar dari Belenggu ADHD dan Autisme. Jakarta: Gramedia.

Woolfolk, E. C.\& Lynch, J. I. 1982. An Integrative Approach to Language Disorder in Children. New York: Grune \& Stratton, Inc.

Yuwono, J. 2009. Memahami Anak Autistik: Kajian Teori dan Empirik. Bandung: Alfabeta. 